\title{
EFEKTIFITAS PELATIHAN PENANGGULANGAN BENCANA DENGAN METODE SIMULASI TERHADAP PERILAKU KESIAPSIAGAAN BENCANA BANJIR PADA SISWA SMAN 2 TUBAN
}

\author{
Kusno Ferianto ${ }^{1}$, Uci Nurul Hidayati ${ }^{2}$ \\ STIKES Nahdlatul Ulama Tuban \\ E-mail :s2gadar2014@gmail.com
}

\begin{abstract}
Indonesia is a disaster-prone region, not only natural disasters but also non-natural disasters. Students are one of the nation's assets that are vulnerable to disasters and there is no readiness in facing disasters. However, based on the experience of students of PMR and SATGAS KESDA member organizations, there has been no disaster simulation training. The purpose of this study was to determine the effect of disaster management training with simulation methods on flood disaster preparedness behavior in students of SMAN 2 Tuban. The research method used was pre-experimental, with one group pre-post test design. The research sample of 28 students who are members of PMR and SATGAS KESDA member organizations were selected by simple random sampling. Disaster Simulation SOP research instrument and preparedness behavior questionnaire. The results obtained most of the students' preparedness behavior before being given training categorized as less prepared behavior, and after given disaster management training, most of the prepared behavior categorized. Statistical test results show that there is an effect of disaster management training with simulation methods on flood disaster preparedness behavior for students of SMAN 2 Tuban with $p$ value $=0.001$ at $\alpha=0.05(p<0.05)$. It is expected that disaster management training using simulation methods can be applied by health workers, education offices, and used as a reference for students in improving their preparedness behavior in the face of flood disasters.
\end{abstract}

\section{Keywords : Disaster Management Training With The Simulation Method, Student Preparedness} Behavior, and Flood Disaster

\begin{abstract}
Abstrak : Indonesia merupakan wilayah rawan bencana tidak hanya bencana alam tapi juga bencana non alam. Siswa merupakan salah satu aset bangsa yang rentan bencana dan tidak ada kesiapan dalam menghadapi bencana. Namun demikian, berdasarkan pengalaman siswa organisasi anggota PMR dan SATGAS KESDA, menunjukkan belum ada pembelajaran pelatihan simulasi bencana. Tujuan dari penelitian ini untuk mengetahui pengaruh pelatihan penanggulangan bencana dengan metode simulasi terhadap perilaku kesiapsiagaan bencana banjir pada siswa SMAN 2 Tuban. Metode penelitian yang digunakan adalah pra eksperimental, dengan rancangan one group pre post test design. Sampel penelitian 28 siswa yang tergabung dalam organisasi anggota PMR dan SATGAS KESDA yang dipilih secara simple random sampling. Instrumen penelitian SOP Simulasi Bencana dan kuisioner perilaku kesiapsagaan. Didapatkan hasil sebagian besar perilaku kesiapsiagaan siswa sebelum diberikan pelatihan dikatagorikan perilaku kurang siap, dan setelah diberikan pelatihan penanggulangan bencana sebagian besar dikatagorikn perilaku siap. Hasill uji statistik menunjukkan bahwa terdapat pengaruh pelatihan penanggulangan bencana dengan metode simulasi terhadap perilaku kesiapsiagaan bencana banjir pada siswa SMAN 2 Tuban dengan nilai $p$ value $=0,001$ pada $\alpha=0,05(p<0,05)$. Diharapkan pelatihan penanggulangan bencana dengan metode simulasi dapat diterapkan oleh tenaga kesehetan, dinas pendidikan, dan dijadikan acuan kepada siswa dalam meningkatkan perilaku kesiapsiagaan menghadapi bencana banjir
\end{abstract}

Kata Kunci : Pelatihan Penanggulangan Bencana Dengan Metode Simulasi, Perilaku Kesiapsiagaan dan Bencana Banjir

\section{PENDAHULUAN}

Bencana yang ada di Indonesia telah banyak terjadi seperti gunung meletus, gempa bumi, tsunami, banjir, angin topan, dan tanah longsor. Faktor utama yang dapat mengakibatkan bencana tersebut menimbulkan korban dan kerugian besar, yaitu kurangnya pemahaman tentang karakteristik bahaya, sikap, atau perilaku yang mengakibatkan penurunan sumber daya alam, kurangnya informasi peringatan dini yang mengakibatkan ketidakberdayaan atau ketidakmampuan dan ketidaksiapan dalam menghadapi bencana (Bakornas, 2007).

Kesiapsiagaan merupakan salah satu bagian dari proses manajemen bencana dan didalam konsep bencana yang berkembang saat ini, pentingnya kesiapsiagaan merupakan salah satu elemen penting dari kegiatan pencegahan 
pengurangan risiko bencana yang bersifat pro-aktif, sebelum terjadinya suatu bencana (LIPI-UNESCO, 2006).

Kesiapsiagaan lebih ditekankan pada usaha menyiapkan kemampuan untuk melakukan kegiatan tanggap darurat dengan cepat dan akurat kaitannya dengan upaya penanggulangan bencana di Indonesia, sekolah sebagai ruang publik memiliki peran nyata dalam membangun ketahanan masyarakat. Kesiapsiagaan sekolah dimaksudkan agar komunitas sekolah tahu, paham, dan peduli terhadap alam sekitar juga meningkatkan keterampilan untuk mengurangi resiko apabila terjadi bencana (Pratiwi, 2016).

Namun pada kenyataan tingkat kesiapsiagaan sekolah di Indonesia saat ini masih rendah. Hal ini menunjukkan bahwa pengupayaan kesiapsiagaan bencana di sekolah menjadi agenda penting bersama yang merupakan upaya dan tanggung jawab dari warga sekolah dan para pemangku kepentingan sekolah.

Menurut data Badan Nasional Penanggulangan Bencana (BNPB) dalam kompas.com pada tahun 2017 kejadian bencana mencatat 2.175 kejadian bencana di Indonesia. Adapun jumlah tersebut terdiri dari banjir 737 kejadian, puting beliung 651 kejadian, tanah longor 577 kejadian, kebakaran hutan dan lahan 96 kejadian, kekeringan 19 kejadian, gempa bumi 18 kejadian, gelombang pasang/abrasi 8 kejadian, serta letusan gunung api 2 kejadian.

Berdasarkan survei awal yang telah dilakukan pada tanggal 14 Maret 2019 di SMAN 2 Tuban dari hasil wawancara pada siswa terdapat dari 10 responden didapatkan 6 anak mengatakan bahwa dia tidak tahu tentang perilaku kesiapsiagaan dalam menghadapi banjir, kurangnya pendidikan dan pelatihan tentang banjir dan belum adanya mata pelajaran yang khusus terkait masalah bencana. Hal tersebut menunjukkan bahwa terjadi masalah kurangnya perilaku kesiapsiagaan siswa dalam menghadapi bencana banjir.

Menurut Lembaga IImu Pengetahuan Indonesia (LIPI) dan United Nations Educational, Scientific and Cultural Organization (UNESCO) (2006, p. 2013) terdapat lima faktor yang mempengaruhi kesiapsiagaan bencana yaitu: pengetahuan dan sikap terhadap risiko bencana, kebijakan dan panduan, rencana untuk keadaan darurat bencana, sistem peringatan bencana, dan kemampuan untuk mobilisasi sumber daya.

- Dampak yang akan terjadi jika kesiapsiagaan rendah yaitu menimbulkan lebih parahnya dampak bencana banjir seperti tingginya korban jiwa, luka berat, banyaknya korban yang mengungsi dan timbul penyakit dari kondisi lingkungan yang rusak. Sehingga ada beberapa media pembelajaran diantaranya adalah multimedia, media audio, media audio visual, media visual dan media realiata yang dapat digunakan untuk meningkatkan pemahaman dan kesiapsiagaan dalam menghadapi banjir salah satunya yaitu metode simulasi.

Simulasi adalah cara penyajian pengalaman belajar dengan menggunakan situasi tiruan untuk memahami tentang konsep, prinsip atau keterampilan tertentu. Simulasi dapat digunakan sebagai metode mengajar dengan asumsi tidak semua proses pembelajaran dapat dilakukan secara langsung pada obyek yang sebenarnya (Sanjaya, 2013)

Hal ini didukung oleh pernyataan oleh Steward \& Wan (2007) dalam penelitiannya tentang peran simulasi didalam manajemen bencana dapat mengukur kesiapan seseorang dalam menghadapi bencana. Menurut Olson et al, 2010 dalam penelitiannya juga menyatakan bahwa pendidikan tentang siaga bencana dengan menggunakan simulasi berupa game atau permainan dapat memberikan hasil yang lebih baik dibandingkan yang tidak menggunakan simulasi.

Berdasarkan uraian di atas peneliti tertarik untuk melakukan penelitian yang berjudul "Pengaruh Pelatihan Penanggulangan Bencana Dengan Metode Simulasi Terhadap Perilaku Kesiapsiagaan Bencana Banjir Pada Siswa SMAN 2 Tuban"

\section{METODE PENELITIAN}

Penelitian ini termasuk jenis penelitian "pra experimental" yang bersifat analitik dengan menggunakan metode penelitian "One-group pra-post test design".

Penelitian ini dilakukan dengan cara memberikan pre test (pengamatan awal) terlebih dahulu sebelum diberikan perlakuan 
$(\mathrm{x})$, setelah diberikan perlakuan, kemudian dilakukan kembali post test (pengamatan akhir). Hal ini dilakukan untuk perbedaan yang dihasilkan antara pre test dan post test.

Populasi penelitian ini adalah Populasi dalam penelitian ini adalah sejumlah 30 siswa SMAN 2 Tuban. Sampel dalam penelitian ini adalah sebagian siswa yang tergabung dalam organisasi anggota PMR dan SATGAS KESDA SMAN 2 Tuban berjumlah 28 anak. Dengan menggunakan teknik sampling "simple random sampling". Instrumen yang digunakan dalam penelitian ini adalah Standart Opererasional Prosedur (SOP) dan kuisioner. Kuesioner terdiri dari 15 pertanyaan yang terdiri dari 3 kelompok pertanyaan. Pertanyaan nomor 15 masuk dalam pengetahuan, pertanyaan nomor 6-10 masuk dalam sikap, dan pertanyaan nomor 11-15 masuk dalam kesiapsiagaan.

Pelatihan Penanggulangan Bencana dengan Metode Simulasi dilakukan selama 1 bulan dalam 3 kali pertemuan yaitu 3 sesi (pertemuan) setiap sesi dengan durasi waktu \pm 60 menit.

\section{HASIL PENELITIAN}

Data Umum Responden

Tabel 1 Karakteristik Responden Berdasarkan Jenis Kelamin Pada Siswa SMAN 2 Tuban.

\begin{tabular}{cccc}
\hline No & Jenis Kelamin & $\boldsymbol{f}$ & Prosentase (\%) \\
\hline 1. & Laki-laki & 9 & $32,1 \%$ \\
2. & Perempuan & 19 & $67,9 \%$ \\
\hline & Jumlah & 28 & $100 \%$ \\
\hline
\end{tabular}

Berdasarkan tabel 1 dapat diketahui bahwa hampir seluruhnya $19(67,9 \%)$ responden yaitu berjenis kelamin perempuan.

Tabel 2 Karakteristik Responden Berdasarkan Umur Pada Siswa SMAN 2 Tuban.

\begin{tabular}{cccc}
\hline No. & Umur & $\boldsymbol{f}$ & Prosentase \\
\hline 1. & 15 tahun & 3 & $10,7 \%$ \\
2. & 16 tahun & 18 & $64.3 \%$ \\
3. & 17 tahun & 7 & $25 \%$ \\
\hline & Jumlah & 28 & $100 \%$ \\
\hline
\end{tabular}

Berdasarkan tabel 2 dapat diketahui bahwa sebagian besar $18(64,3 \%)$ responden yaitu berumur 16 tahun.

\section{Data Khusus Responden yang diperoleh pada penelitian}

Tabel 3 Skor Perilaku Kesiapsiagaan Sebelum diberikan Pelatihan Penanggulangan Bencana dengan Metode Simulasi di SMAN2 Tuban Pada Bulan Mei 2019.

\begin{tabular}{cccc}
\hline No. & $\begin{array}{c}\text { Kategori Perilaku } \\
\text { Kesiapsiagaan }\end{array}$ & $\boldsymbol{f}$ & Prosentase \\
\hline 1. & Siap & 5 & $17,9 \%$ \\
2. & Kurang Siap & 21 & $75 \%$ \\
3. & Tidak Siap & 2 & $7,1 \%$ \\
\hline & Jumlah & 28 & $100 \%$ \\
\hline
\end{tabular}


Berdasarkan tabel 3 dapat diketahui bahwa sebagian besar 21 (75\%) responden yaitu kategori perilaku kesiapsiagaan kurang siap.

Tabel 4 Skor Perilaku Kesiapsiagaan Setelah diberikan Pelatihan Penanggulangan Bencana dengan Metode Simulasi di SMAN2 Tuban Pada Bulan Mei 2019.

\begin{tabular}{lccc}
\hline No. & $\begin{array}{c}\text { Kategori Perilaku } \\
\text { Kesiapsiagaan }\end{array}$ & $\boldsymbol{f}$ & Prosentase \\
\hline 1. & Siap & 21 & $75 \%$ \\
2. & Kurang Siap & 7 & $25 \%$ \\
3. & Tidak Siap & 0 & $0 \%$ \\
\hline & Jumlah & 28 & $100 \%$ \\
\hline
\end{tabular}

Berdasarkan tabel 4 dapat diketahui bahwa sebagian besar 21 (75\%) responden yaitu kategori perilaku kesiapsiagaan siap.

\section{Analisis Pengaruh Pelatihan \\ Penanggulangan Bencana Dengan Metode Simulasi Terhadap Perilaku Kesiapsigaan Bencana Banjir Pada Siswa SMAN 2 Tuban}

Berdasarkan hasil analisis dapat diketahui bahwa sebelum diberikan pelatihan penanggulangan bencana dengan metode simulasi responden sebanyak 21 (75\%) memiliki perilaku kesiapsiagaan kurang siap, sedangkan setelah diberikan pelatihan penanggulangan bencana dengan metode simulasi responden sebanyak 21 $(75 \%)$ memiliki perilaku kesiapsiagaan siap lebih tinggi sebelum diberikan perlakuan.

Data yang diperoleh dianalisis menggunakan uji Wilcoxon dengan tingkat kemaknaan $\alpha=0,05$ didapatkan hasil $p=$ 0,001 dimana nilai $p<\alpha \quad(0,001<0,05)$ maka dapat disimpulkan bahwa $\mathrm{H}_{1}$ diterima artinya terdapat Pengaruh Pelatihan Penanggulangan Bencana Dengan Metode Simulasi Terhadap Perilaku Kesiapsiagaan Siswa SMAN 2 Tuban.

\section{PEMBAHASAN}

\section{Perilaku Kesiapsiagaan Sebelum diberikan Pelatihan Penanggulangan Bencana dengan Metode Simulasi.}

Berdasarkan tabel 3 dapat diketahui bahwa sebagian besar 21 (75\%) responden yaitu kategori perilaku kesiapsiagaan kurang siap. Menurut Mulyadi,dkk (2015) terdapat beberapa faktor yang berperan dalam meningkatkan perilaku kesiapsiagaan menghadapi bencana banjir. Perilaku kesiapsiagaan sangat berperan terhadap saat menghadapi bencana. Semakin baik perilaku tentang bencana, maka seseorang akan lebih siap dalam menghadapi bencan banjir, dimana dalam hal setiap penentuan sikap pengetahuan, pola pikir, keyakinan serta emosi memegang peranan penting.

Stuart dan Laraia (2008) dalam Pinilih (2012) menyatakan bahwa usia berhubungan dengan pengalaman seseorang, kemampuan memanfaatkan sumber dukungan dan keterampilan dalam mekaisme koping. Faktor usia mempengaruhi terhadap peningkatan karena semakin tinggi usianya anak, mereka mampu mencerna sikap positif dan negatif yang bersosialisasi. Jenis kelamin juga mempengaruhi perilaku kesiapsiagaan dalam menghadapi bencana banjir.. Umur responden berkisar 15-17 tahun.

Hampir seluruhnya responden berjenis kelamin perempuan sebanyak 19 (67.9\%) sedangkan sebagian kecil responden berjenis kelamin laki-laki sebanyak 9 $(32,1 \%)$, bahwa banyak perilaku yang kurang siap didomisili laki-laki dibandingkan perempuan.

Hasil analisa data dan interprestasi data yang di peroleh dari siswa dalam menghadapi bencana banjir berjumlah 28 responden yang tergabung dalam anggota PMR (Palang Merah Remaja) dan SATGAS KESDA (Satuan Petugas Ketahanan Smada) sebelum di berikan pelatihan penanggulangan bencana banjir dengan metode simulasi di SMAN 2 Tuban menunjukkan bahwa sebagian besar responden mempunyai perilaku kesiapsiagaan kurang siap, hal ini di karenakan siswa tidak memiliki pengalaman 
dan pengetahuan tentang bahaya bencana banjir dan tidak pernah mengikuti pelatihan lainnya. Responden cenderung tidak memiliki pengetahuan tentang pemahaman kesiapsiagaan dalam menghadapi suatu bencana atau bencana banjir, dan apabila tidak di berikan pelatihan penanggulagan bencana dengan metode simulasi terhadap siswa dalam menghadapi bencana banjir dapat mengakibatkan perilaku kesiapsiagaan siswa menjadi kurang siap.

\section{Perilaku Kesiapsiagaan Setelah diberikan Pelatihan Penanggulangan Bencana dengan Metode Simulasi.}

Berdasarkan table 4 dapat diketahui bahwa sebagian besar 21 (75\%) responden yaitu kategori perilaku kesiapsiagaan siap.

Menurut Hasibuan dan Mudjiono (2008) simulasi adalah tiruan atau perbuatan yang hanya pura-pura saja (dari fakta stimulate yang artinya pura-pura atau berbuat seolaholah; dan stimulation artinya tiruan atau perbuatan yang pura-pura saja).

Hasil analisa data dan interprestasi data yang di peroleh dari siswa dalam menghadapi bencana banjir berjumlah 28 responden yang tergabung dalam anggota PMR (Palang Merah Remaja) dan SATGAS KESDA (Satuan Petugas Ketahanan Smada) setelah di berikan pelatihan penanggulangan bencana banjir dengan metode simulasi di SMAN 2 Tuban bahwa sebagian besar responden mempunyai perilaku kesiapsiagaan siap. Simulasi dapat digunakan sebagai metode mengajar dengan asumsi tidak semua proses pembelajaran dapat dilakukan secara langsung pada obyek yang sebenarnya.

Manfaat dari pemberian metode simulasi ini dapat dibuktikan dengan peningkatan hasil dari data pre-test dan post-test yang ditandai dengan perubahan perilaku yang dinilai dalam lembar kuesioner secara individual. Pelatihan Penanggulangan Bencana dengan Metode Simulasi dilaksanakan selama 1 bulan dalam 3 kali pertemuan. Setiap sesi dalam pertemuan berlangsung selama 2 jam. Setelah intervensi atau kegiatan selesai di laksanakan, selanjutnya di lakukan penilaian akhir (post test). Responden yang mengikuti kegiatan dengan antusias dan aktif terbukti memperoleh manfaat dan hasil yang signifikan dari kegiatan ini. Hal ini terbukti bahwa metode simulasi sangat efektifdan interaktif untuk meningkatkan perilaku kesiapsiagaan siswa dalam menghadapi bencana banjir.

\section{Analisis Pengaruh Pelatihan Penanggulangan Bencana Dengan Metode Simulasi Terhadap Perilaku Kesiapsiagaan Bencana Banjir Pada Siswa SMAN 2 Tuban.}

Hasil Analisa data yang digunakan pada penelitian ini adalah uji wilcoxon dengan tingkat kemaknaan $\alpha=0,05$ didapatkan hasil Asymp. Sig. (2-tailed) $p=$ 0,001 dimana nilai $p<\alpha \quad(0,001<0,05)$ maka dapat disimpulkan bahwa $\mathrm{H}_{1}$ diterima artinya terdapat Pengaruh Pelatihan Penanggulangan Bencana Dengan Metode Simulasi Terhadap Perilaku Kesiapsiagaan Bencana Banjir Pada siswa.

Menurut Olson et,al (2010) dalam penelitiannya menyatakan bahwa pendidikan tentang siaga bencana dengan menggunakan simulasi berupa game atau permainanan dapat mmberikan hasil yang lebih baik dibandingkan yang tidak menggunakan simulasi. Pemberian simulasi dengan menggunakan metode role playing atau game dapat dilakukan untuk membantu mengendalikan aktivitas yang berlebihan (hiperaktif), melatih kemampuan mempertahankan perhatian pada objek tertentu, dan mengendalikan tingkat angresivitas.

Dari hasil penelitian ini menujukkan bahwa dengan pemberian pengetahuan menggunakan pelatihan penanggulangan bencana dengan metode simulasi dapat meningkatkan perilaku kesiapsiaagaan siswa dalam menghadapi bencana banjir, merupakan hal penting untuk siswa berinteraksi dalam suatu lingkungan adanya kemampuan berinteraksi menjadi kunci untuk memperkaya pengalaman pribadi pada siswa.

Berdasarkan data yang diketahui bahwa sebagian besar responden sebelum diberikan pelatihan penanggulangan bencana dengan metode simulasi memiliki perilaku kesiapsiagaan kurang siap sedangkan sesudah diberikan pelatihan penanggulangan bencana dengan metode simulasi memiliki perilaku kesiapsiagaan siap. Hal ini menunjukkan adanya peningkatan dalam pemberian pelatihan dengan metode simulasi terhadap perilaku 
kesiapsiagaan siswa karena pelatihan penanggulangan bencana dengan metode simulasi memberikan dampak positif bagi siswa dalam menghadapi bencana banjir dan metode simulasi dapat meningkatkan perilaku kesiapsiaagaan siswa dalam menghadapi bencana banjir, merupakan hal penting untuk siswa berinteraksi dalam suatu lingkungan adanya kemampuan berinteraksi menjadi kunci untuk memperkaya pengalaman pribadi pada siswa.

Hasil penelitian menunjukkan bahwa terdapat Pengaruh Pelatihan Penanggulangan Bencana Dengan Metode Simulasi Terhadap Perilaku Kesiapsiagaan Bencana Banjir Pada Siswa SMAN 2 Tuban menunjukkan hasil yang efektif untuk melatih keterampilan tertentu, baik yang bersifat profesional maupun bagi kehidupan sehari-hari dan untuk menumbuhkan daya kreatif siswa.

Keberhasilan pelaksanaan simulasi karena dukungan dari berbagai pihak, diantaranya terdapat guru atau pelatih yang mendampingi saat pelaksanaan berlangsung, dukungan dari orang tua dan keinginan siswa untuk menambah pengalaman di kehidupan siswa, siswa sangat antusias mengikuti simulasi sampai selesai dan aktif memberikan feedback saat pelatih atau guru memberikn pertanyaan,

\section{KESIMPULAN}

Dari hasil penelitian ini dapat disimpulkan bahwa sebagian besar responden sebelum diberikan pelatihan penanggulangan bencana dengan metode simulasi di SMAN 2 Tuban mempunyai perilaku kesiapsiagaan yang kurang siap. Hampir seluruhnya responden setelah diberikan pelatihan penanggulangan

\section{DAFTAR PUSTAKA}

Bakornas PB, 2007. Pengenalan Karakteristik Bencana dan Upaya Mitigasi di Indonesia. Jakarta: Badan Nasional Penanggulangan Bencana.

Badan Nasional Penanggulangan Bencana (BNPB).2017. 2018/22/01. Dari https://nasional.kompas.com/read/20 17/12/05/17200331/sepanjang2017-bnpb-mencatat-2175-kejadianbencana-di-indonesia bencana dengan metode simulasi di SMAN 2 Tuban mempunyai perilaku kesiapsiagaan yang siap. Terdapat pengaruh pelatihan penanggulangan bencana dengan metode simulasi terhadap perilaku kesiapsiagaan bencana banjir pada siswa SMAN 2 Tuban.

\section{SARAN}

Adapun saran yang diberika sebagai berikut. Bagi Peneliti Selanjutnya, diharapkan bagi peneliti selanjutnya dapat membuat dan melakukan pengembangan penelitian dengan pendekatan teori lainnya tentang faktor yang mempengaruhi perilaku kesiapsiagaan siswa dalam menghadapi bencana banjir yang tidak hanya dipengaruhi oleh pengalaman pribadi, tingkat pendididkan dan pengaruh orang lain yang di anggap penting saja melainkan faktor yang lainnnya.

Bagi Institusi, diharapkan dapat dijadikan untuk pengembangan pembelajaran mengenai Pelatihan dalam penanganan dan perilaku kesiapsiagaan. Bagi institusi pendidikan supaya terus dapat memperbanyak sumber bacaan baik buku, jurnal, maupun literatur lainnya mengenai keperawatan gawat darurat khususnya yang berhubungan dengan penatalaksanaan Bencana dalam peningkatan perilaku kesiapsiagaan siswa dalam menghadapi bencana banjir.

Bagi Responden, diharapkan responden dapat menerapka kegiatan simulasi bencana banjir setelah diberikan pelatihan tersebut. Kegiatan simulasi bencana sangat efektif untuk mengantisipasi sebelum adanya bencana banjir datang, efektivitasnya akan lebih baik jika responden dapat melaksanakan kegiatan simulasi sesuai dengan prosedur.

Harahap, Effendi M. 2015. Pengaruh Pengetahuan Dan Sikap Terhadap Kesiapsiagaan Masyarkat Dalam Menghadapi Bencana Banjir Di Desa Perkebunan Bukit Lawang Kecamatan Bahorok 2011. Jurnal IImiah Keperawatan IMELDA. Vol 1, No.1.

LIPI dan UNESCO. $2006 . \quad$ Kajian Kesiapsiagaan masyarakat dalam 
Menghadapi Ancaman Bencana Alam. LIPI Press, Jakarta.

Pratiwi. 2016. Pengaruh Pelatihan Penanggulangan Bencana Gempa Bumi Terhadap Kesiapsiagaan Palang Merah Remaja (PMR) SMAN 1 Pleret Bantul Dalam Menghadapi Becana. FIK UNISA. Yogyakarta

Sanjaya. 2013. Pengaruh Pemberian Metode Simulasi Siaga Bencana Gempa Bumi Terhadap Kesiapsiagaan Anak Di Yogyakarta. Jurnal Keperawatan Soedirman. Volume 11, No. 3.

Steward, D \& Wan, T.T.2007. The Role of Simulation and Modeling in Disaster Management. $J$ Med Syst. 3, 125-130

Fathoni. 2015. Pengaruh Pengetahuan Dan Sikap Terhadap Kesiapsiagaan Masyarkat Dalam Menghadapi Bencana Banjir Di Desa Perkebunan Bukit Lawang Kecamatan Bahorok Tahun 2011. Jurnal IImiah Keperawatan IMELDA. Volume 1, No. 1.

Olson, D.K, Scheller, A, Larson, S, Lindeke, L \& Edwardson, S. 2010. Using Gaming Simulation to Evaluate Bioterrorism and Emergency Readiness Education. Public Health Rep, May-June 2010, 125, 468-477
Purwoko, Alif, dkk. 2015. Pengaruh Pengetahuan dan Sikap Tentang Risiko Bencana Banjir Terhadap Kesiapsiagaan Remaja Usia 15-18 Tahun Dalam Menghadapi Bencana Banjir Di Kelurahan Pedurungan Kidul Kota Semarang. Jurnal Geografi Vol 1,

Tierney, Sutton. 2015. Analisis Tingkat Kesiapsiagaan Masyarakat Dalam Menghadapi Bencana Banjir Di Kecamatan Meurebo Kabupaten Aceh Barat. Jurnal IImu Kebencanaan. Volume 2, No.1.

Badan Penanggulangan Bencana Daerah (BPBD).2017.2018/22/01. Dari https://jatim-tribunnewscom.cdn.ampproject.org/v/jatim.tribu nnews.com/amp/2017/02/13/87-kalijawa-timur-diteriang-bencana-alampada-januari-2017. 